\title{
New species of dinoflagellate cysts from the Campanian-Danian chalks at Hallembaye and Turnhout (Belgium) and at Beutenaken (the Netherlands)
}

\author{
HAMID SLIMANI \\ Université Mohammed V, Institut Scientifique, Département de Géologie, Avenue Ibn Batouta, BP 703, Rabat-Agdal, Maroc. \\ (e-mail: slimani@israbat.ac.ma)
}

\begin{abstract}
A palynological study of Campanian-Danian chalks from the quarries at Beutenaken and Hallembaye (Maastricht region) and from a borehole at Turnhout (northern Belgium) has revealed the presence of seven new species and subspecies of dinoflagellate cysts: Exochosphaeridium? Masureae sp. nov., Leberidocysta chlamydata subsp. schiolerii subsp. nov., Odontochitina streelii sp. nov., Pervosphaeridium septatum sp. nov., Spiniferites ramosus subsp. pterocoelus subsp. nov., Stephodinium? spinosum sp. nov. and Xenascus wetzelii sp. nov. Nexosispinum? complicatum described by Slimani (1996) as a new species is now a junior synonym of Pulchrasphaera minuscula Schiøler et al. (1997). J. Micropalaeontol. 20(1): 1-11, July 2001.
\end{abstract}

\section{INTRODUCTION}

Upper Cretaceous sediments have been sampled in the quarries of Beutenaken and Hallembaye (Figs 1-3) and in the cored borehole at Turnhout (Fig. 4). In an earlier publication (Slimani, 1994) six new genera were defined, 55 new species described and some new combinations and emendations proposed. In a later paper (Slimani, 1996) eight new taxa were described in French. However, according to the International Code of Botanical Nomenclature (1994 edition, Article 36.3) new taxa can only be validated if the diagnosis or description is given in Latin or
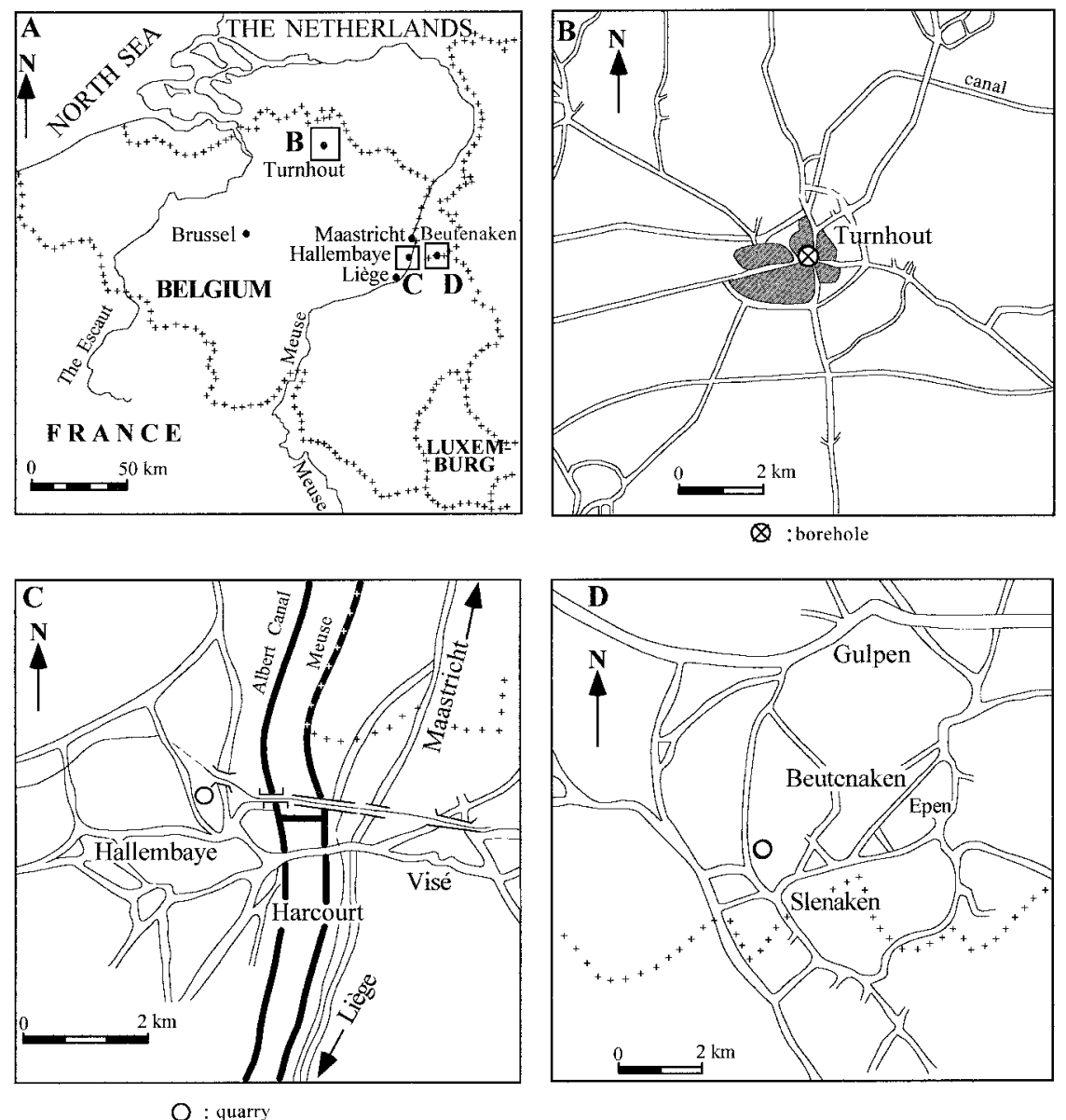

Fig. 1. Location of the Beutenaken and Hallembaye quarries and the Turnhout borehole (B, location of the Turnhout borehole; C, location of the Hallembaye quarry; D, location of the Beutenaken quarry). 


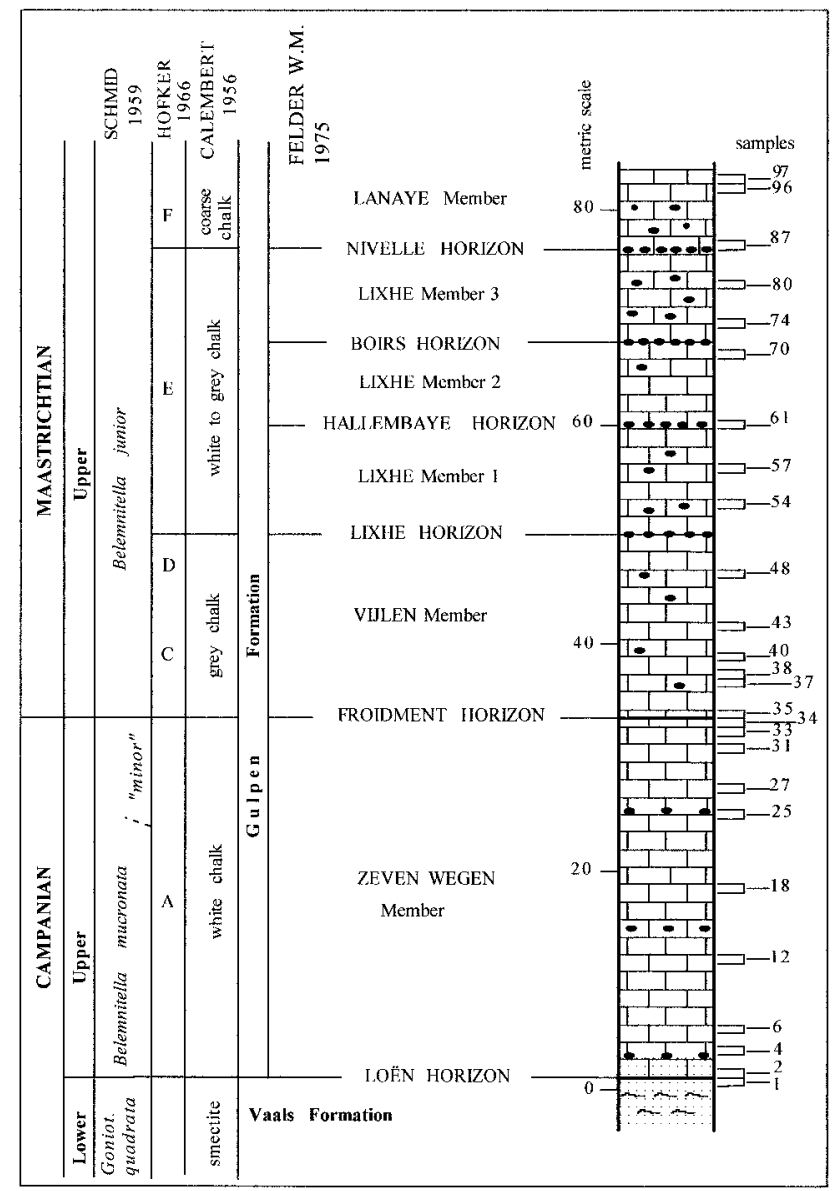

Fig. 2. Lithology, biostratigraphy and sampling of the Hallembaye quarry (Goniot. quadrata=Gonioteuthis quadrata) (modified from Robaszynski et al., 1985).

English. To meet this recommendation the present paper gives the diagnosis of the seven new taxa in English.

\section{SYSTEMATIC PALYNOLOGY}

Holotypes and paratypes of the new species are conserved in the Micropalaeontological collections of the Laboratory of Palaeontology, Department of Geology, University of Gent, Belgium, under the references given in the text.

Division Pyrrhophyta Pascher, 1914

Class Dinophyceae Fritsch, 1929

Order Peridiniales Haeckel., 1894

Genus Exochosphaeridium Davey, Downie, Sarjeant \& Williams, 1966b

Exochosphaeridium? masureae sp. nov.

(Pl. 1, figs 1, 2, 4, 5; Pl. 2, fig. 10)

1983 'Exochosphaeridium? acuminatum' Wilson, 1974; Foucher: table of stratigraphic distribution.

1985 'Exochosphaeridium? acuminatum' Wilson; Foucher in Robaszynski et al:: figs 20, 21.

1985a 'Exochosphaeridium? acuminatum' Wilson; Masure: fig. $1 \mathrm{~F}$.

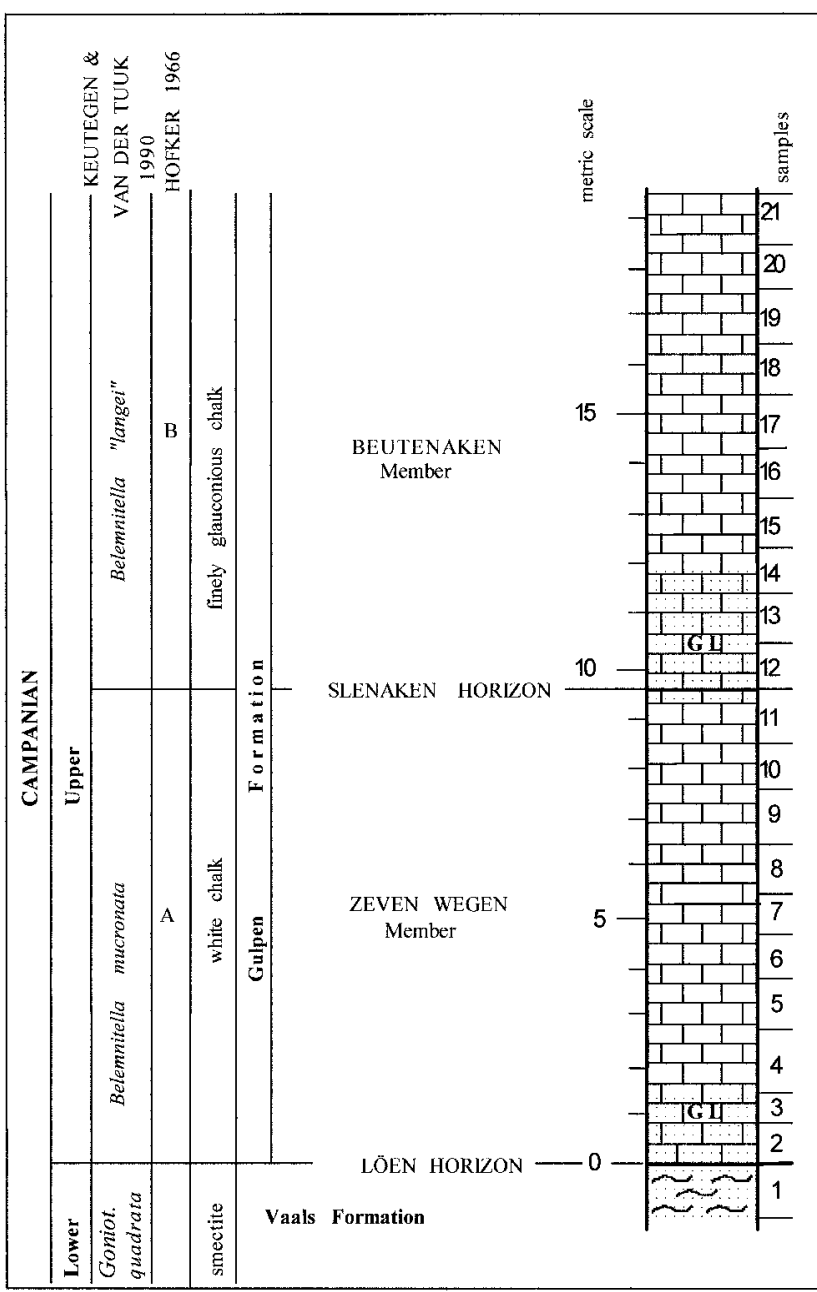

Fig. 3. Lithology, biostratigraphy and sampling of the Beutenaken quarry (Goniot. quadrata=Gonioteuthis quadrata) (modified from Robaszynski et al., 1985).

1989 'Exochosphaeridium? acuminatum' Wilson; Masure; Lentin \& Williams: 133.

1993 'Exochosphaeridium? acuminatum' Wilson; Masure; Lentin \& Williams: 217.

1996 Exochosphaeridium? masurii sp. nov. Slimani: 373-374, pl. 1, figs $\mathrm{H}-\mathrm{L}$.

1998 'Exochosphaeridium? masureae' Slimani, 1996; Williams, Lentin \& Fensome: 222.

Type species. Exochosphaeridium bifidum (Clarke \& Verdier, 1967) Clarke et al., 1968 subsp. bifidum.

Derivation of name. In honour of Dr Edwige Masure, Laboratory of Micropalaeontology, Université Pierre et Marie Curie, Paris, France.

Diagnosis. Skolochorate cyst with ovoidal to spherical central body. Periphragm and endophragm smooth and appressed between processes. Numerous hollow and closed processes, wide proximally with a subcircular to oval cross-section, simple and acuminate distally or subdivided in smaller acuminate processes. Process often connected proximally and give a reticulate aspect 


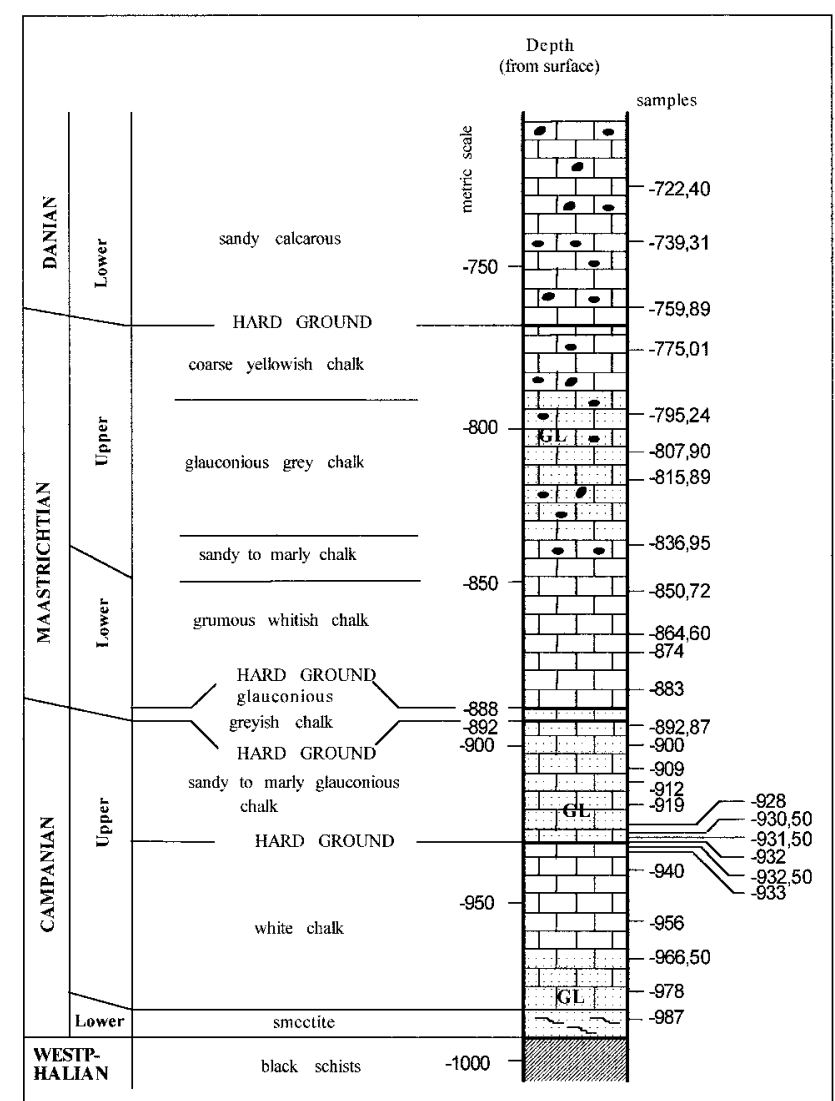

Fig. 4. Lithology and sampling of the Turnhout borehole (GL=glauconite).

of the cyst. Vague paratabulation partially indicated by more or less defined groups of precingular, paracingular, postcingular and sulcal processes. Levorotatory paracingulum, often somewhat more clearly indicated by an alignment of two rows of processes. Distinct apical process solid, larger than the other processes, and irregularly branched. Precingular archeopyle $\mathrm{P}\left(3^{\prime \prime}\right)$ with free operculum.

Holotype. Turnhout $-956 \mathrm{~m}$, preparation 8, coord. E.F. V51/4 (Pl. 1, figs 1, 2).

Paratype. Hallembaye sample 18, preparation 3, coord. E.F. F32/3 (Pl. 2, fig. 10).

Type locality \& horizon. Turnhout $-956 \mathrm{~m}$. Campanian.

Dimensions. Holotype: diameter of central body $-65 \mu \mathrm{m}$, length of processes $-6-20 \mu \mathrm{m}$; paratype: diameter of central body $50 \mu \mathrm{m}$, length of processes $-6-16 \mu \mathrm{m}$; other specimens: diameter of central body $-50-70 \mu \mathrm{m}$, length of processes $-6-14 \mu \mathrm{m}$. Specimens measured: 10 .

Stratigraphical range. Beutenaken: sample 1-11 (Lower-Upper Campanian); Hallembaye: sample 12-27 (Upper Campanian); Turnhout: -978 up to $-933 \mathrm{~m}$ (Upper Campanian).

Stratigraphical and geographical distribution. Belgium [in Louwye (1991): Campanian]; Belgium and the Netherlands [in Wilson (1974): Late Campanian (lower part of B. mucronata Zone, Maastricht region]; France [Foucher (1983, 1985):
Campanian; Masure (1985a): Campanian; Autoroute A10, Masure (1985b): Campanian, Charente].

Remarks. The attribution of the species to the genus Exochosphaeridium is uncertain as the cyst wall in other Exochosphaeridium species is, in general, fibrous while it is smooth in Exochosphaeridium? masureae. The processes of E? masureae resemble those of Florentinia ferox (Deflandre, 1937) and Raetiaedinium belgicum Slimani (1994). However Florentinia and Raetiaedinium respectively present a combination archeopyle (apical paraplates+one precingular paraplate) and precingular (2P) archeopyle, while in E? masureae one encounters a precingular $\mathrm{P}\left(3^{\prime \prime}\right)$ archeopyle.

Genus Leberidocysta Stover \& Evitt, 1978

Leberidocysta chlamydata (Cookson \& Eisenack, 1962) Stover \& Evitt, 1978 subsp. schiølerii subsp. nov. (Pl. 1, figs 10-13; Pl. 2, figs 5, 6, 9)

1971 Hexagonifera chlamydata Cookson \& Eisenack, 1962; Wilson: pl. 4, fig. 8.

1986 Leberidocysta chlamydata (Cookson \& Eisenack, 1962) Stover \& Evitt, 1978; Marheinecke: pl. 1, fig. 4, pl. 17, fig. 4. 1991 Leberidocysta chlamydata (Cookson \& Eisenack, 1962) Stover \& Evitt, 1978; Kirsch: 124, pl. 4, figs 5, 8.

1992 Leberidocysta chlamydata (Cookson \& Eisenack, 1962) Stover \& Evitt, 1978; Marheinecke: 88-89, pl. 18, figs 4, 8, 10, 11.

1993 Leberidocysta aff. chlamydata (Cookson \& Eisenack, 1962) Stover \& Evitt, 1978; Schiøler \& Wilson: 347, pl. 3, fig. 10.

1996 Leberidocysta chlamydata (Cookson \& Eisenack, 1962) Stover \& Evitt, 1978 subsp. schiolerii sp. nov. Slimani: 375, pl. 1, figs $\mathrm{A}-\mathrm{G}$.

1998 Leberidocysta chlamydata (Cookson \& Eisenack, 1962) Stover \& Evitt, 1978 subsp. 'schioleri' Slimani, 1996; Williams, Lentin \& Fensome: 361.

Type species. Leberidocysta chlamydata (Cookson \& Eisenack, 1962) Stover \& Evitt, 1978.

Derivation of name. In honour of Dr Poul Schiøler, Geological Survey of Denmark, Copenhagen, Denmark.

Diagnosis. Holocavate oval to ellipsoidal cyst with norrow pericoel. The grossly verrucose endophragm and the smooth or slightly stippled periphragm are connected by few processes in apical and antapical polar areas. Solid processes are slightly expanded distally. Apical archaeopyle (tA) with zig-zag margin, sulcal notch and free operculum.

Holotype. Turnhout -933 m, preparation 3, coord. E.F. G37 (Pl. 1, figs 10-13).

Paratype. Turnhout $-933 \mathrm{~m}$, preparation 4, coord. E.F. E43/1 (Pl. 2, fig. 5).

Type locality \& horizon. Turnhout $-933 \mathrm{~m}$. Campanian.

Dimensions. Holotype: length of pericyst (with operculum) $70 \mu \mathrm{m}$, width of pericyst $-50 \mu \mathrm{m}$, length of endocyst $-46 \mu \mathrm{m}$, width of endocyst $-34 \mu \mathrm{m}$; paratype: length of pericyst (with operculum) $-64 \mu \mathrm{m}$, width of pericyst $-56 \mu \mathrm{m}$, length of endocyst $-40 \mu \mathrm{m}$, width of endocyst $-32 \mu \mathrm{m}$; other specimens (without operculum): length of pericyst $-60-65 \mu \mathrm{m}$, width of pericyst $-50-62 \mu \mathrm{m}$, length of endocyst $-40-50 \mu \mathrm{m}$, width of endocyst $-32-42 \mu \mathrm{m}$. Specimens measured: 7. 

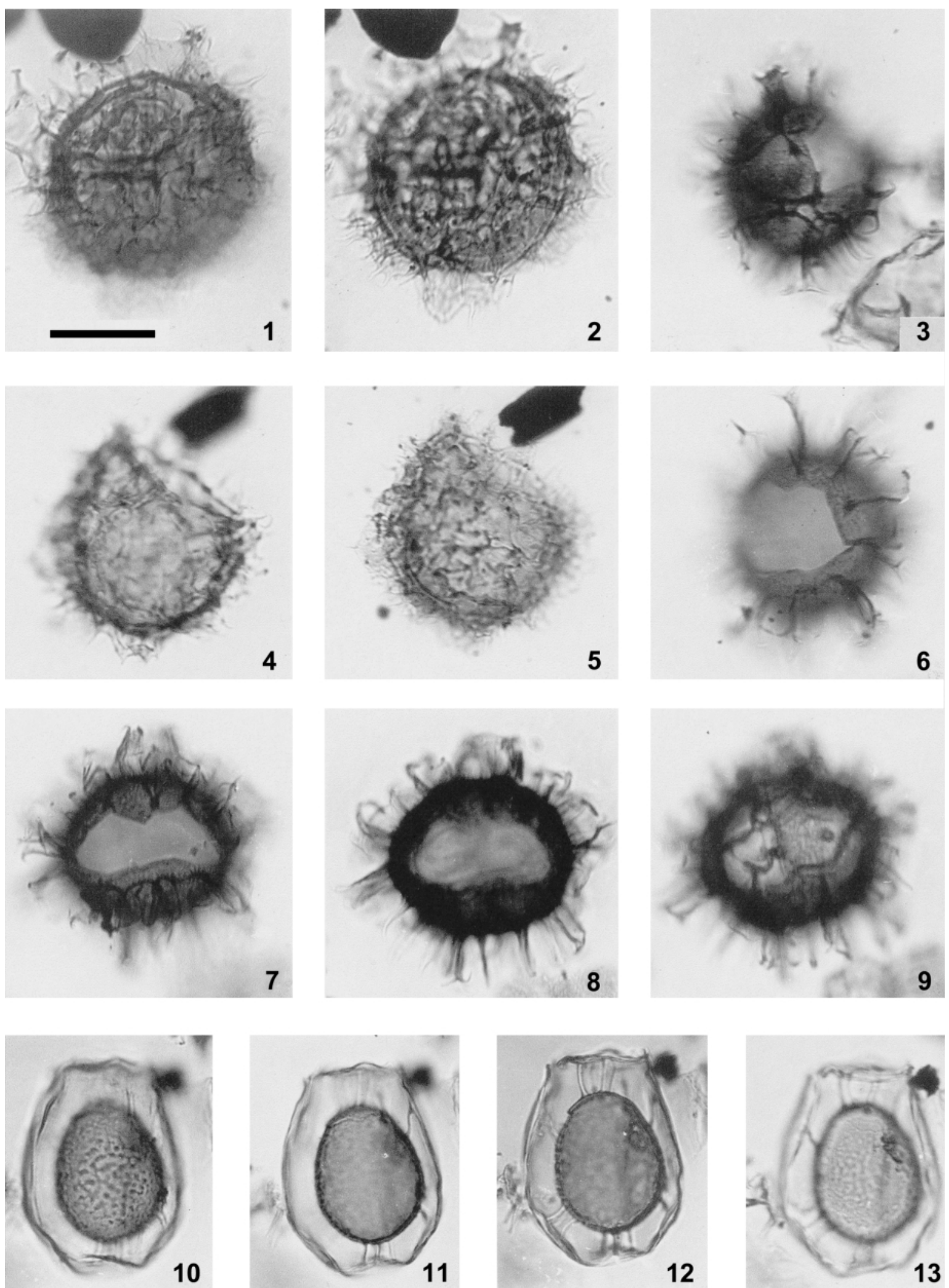
Stratigraphical occurrence. Beutenaken: sample 2-20 (Upper Campanian); Hallembaye: sample 4-74 (Lower CampanianUpper Maastrichtian); Turnhout: -96650 up to $-75989 \mathrm{~m}$ (Upper Campanian-Danian).

Stratigraphical and geographical distribution. Germany [Marheinecke (1986, 1992): Early-Late Maastrichtian; Kirsch (1991): Middle Maastrichtian]; Belgium [in Louwye (1991): Cenomanian-Campanian]; Belgium, Denmark and The Netherlands: Wilson (1971, 1974): Late Campanian-Late Maastrichtian (Ia-Vb Zone of Wilson, 1974)]. Denmark [Schiøler \& Wilson (1993): Maastrichtian].

Remarks. Leberidocysta chlamydata subsp. schiolerii subsp.nov. differs from Leberidocysta chlamydata sensu stricto by the presence of processes connecting endo- with periphragm.

Genus Nexosispinum Davey, 1979

Nexosispinum? complicatum Slimani (1996)=Pulchrasphaera minuscula Schiøler et al. (1997)

(Pl. 3, figs 6-11)

?1986 Dinoflagellate type C in Ioannides: 41-42, pl. 24, figs 5, 7-9, 11, 12 .

1996 Nexosispinum? complicatum sp. nov. Slimani: 377, pl. 3, figs D, E, pl. 4, figs H, J-N.

1997 Pulchrasphaera minuscula sp. nov. Schiøler et al:: 89, pl. I, figs $1-6$, pl. II, figs 1-8.

1998 'Nexosispinum? complicatum' Slimani, 1996; Williams, Lentin \& Fensome: 422.

Type species. Nexosispinum hesperum Davey, 1979.

Diagnosis. Proximate cyst with spherical to subspherical central body. Autophragm densely ornate by nontabular solid and short processes. Varied distal end of process: acuminate, bifid, digitate or complex and rarely connected. Probably a precingular archaeopyle $2 \mathrm{P}\left(3^{\prime \prime}, 4^{\prime \prime}\right)$. Free operculum formed by loss of two paraplates.

Dimensions. Total diameter $-30-38 \mu \mathrm{m}$; length of processes 1.5-8 $\mu \mathrm{m}$. Specimens measured: 11 .

Stratigraphical occurrence. Turnhout: -86460 up to -739 31 m (Lower Maastrichtian-Danian).

Stratigraphical and geographical distribution. The Netherlands [Schiøler et al. (1997): Upper Maastrichtian of the ENCI Quarry, Maastricht].

Remarks. In 1996, Nexosispinum? complicatum was identified as a new species but not validly published, because the description was not given in Latin or English. Nexosispinum? complicatum and Pulchrasphaera minuscula Schiøler et al. (1997) are identified as the same species. Therefore, Nexosispinum? complicatum Slimani (1996) is junior synonym of Pulchrasphaera minuscula Schiøler et al. (1997).
Genus Odontochitina Deflandre, 1935; emend. Davey, 1970; emend. Bint, 1986

Odontochitina streelii sp. nov.

(Pl. 2, figs 1, 2; Pl. 3, fig. 5)

1996 Odontochitina streelii sp. nov. Slimani: 377-378, fig. 6, pl. 3, figs A-C.

1998 'Odontochitina streelii' Slimani, 1996; Williams, Lentin \& Fensome: 433.

Type species. Odontochitina operculata (O. Wetzel, 1933) Deflandre \& Cookson, 1955.

Derivation of name. In honour of Prof. Dr Maurice Streel, Laboratory of Palaeontology, University of Liège, Liège, Belgium.

Diagnosis. Cornucavate cyst with three slender horns which are pointed at their distal end. Postcingular horn shorter than antapical horn. Periphragm and endophragm appressed between horns. Periphragm striated and tabulate by low crests, corniform gonyaulacoid paratabulation; 6 precingulars (2-1i), 5 precingulars (au-?e), 5-6 postcingulars (II-VIi), X sulcals, 1 antapical (Y) and 1 posterior intercalary. Slightly levorotatory paracingulum. Apical archaeopyle with circular and continuous margin and with free operculum. Number of apical paraplates not known because the operculum has not been observed.

Holotype. Beutenaken sample 20, preparation 1, coord. E.F. X28/3 (Pl. 2, figs 1, 2).

Paratype. Beutenaken sample 20, preparation 2, coord. E.F. F42/4 (P1. 3, fig. 5).

Type locality \& horizon. Beutenaken sample 20. Campanian.

Dimensions. Holotype: length of central body (without operculum) $-66 \mu \mathrm{m}$, width of central body $-64 \mu \mathrm{m}$, length of lateral horn $-72 \mu \mathrm{m}$, length of antapical horn $-98 \mu \mathrm{m}$; paratype: length of central body (without operculum) $-46 \mu \mathrm{m}$, width of central body $-52 \mu \mathrm{m}$, length of lateral horn $-74 \mu \mathrm{m}$, length of antapical horn $-90 \mu \mathrm{m}$; other specimens: length of central body (without operculum) $-50-60 \mu \mathrm{m}$, width of central body $-50-60 \mu \mathrm{m}$, length of horns $-70-110 \mu \mathrm{m}$. Specimens measured: 7 .

Stratigraphical occurrence. Beutenaken: sample 6-21 (Upper Campanian-Lower Maastrichtian); Turnhout: -933 up to - 89287 m (Upper Campanian-Lower Maastrichtian).

Remarks. Odontochitina streelii sp. nov. differs from Odontochitina operculata O. Wetzel (1933) by the striate ornamentation of the periphragm, indicating a tabulation. O. streelii sp. nov. differs from Odontochitina wetzelii sp. nov. and Odontochitina sp. A of Kirsch (1991) by its narrow, simple and often pointed horns, by its thinner and finely reticulate endophragm, by the absence of processes and by the striations of the periphragm. In Odontochitina costata Alberti (1961) the horns only are striate and they are, moreover, perforate.

\section{Explanation of Plate}

Figs 1,2,4,5. Exochosphaeridium? masureae sp. nov.: 1, holotype, Turnhout $-956 \mathrm{~m}$, preparation 8, E.F. V51/4, dorsal surface in high focus; 2, same specimen, ventral surface in low focus; 4, Turnhout $-956 \mathrm{~m}$, preparation 3, E.F. J24/(3), left lateral view in high focus; 5 , same specimen, right lateral view in low focus. Figs 3,6-9. Pervosphaeridium septatum sp. nov.: 3, Turnhout $-933 \mathrm{~m}$, preparation 3, E.F. K43/1, left lateral view in high focus; 6, Turnhout -933 m, preparation 5, E.F. W39/4-X39/2, dorsal surface in high focus; 7, holotype, Turnhout $-933 \mathrm{~m}$, preparation 10, E.F. U33, dorsal surface in high focus; 8, same specimen, sectional focus on processes; 9, same specimen, ventral surface in low focus. Figs 10-13. Leberidocysta chlamydata (Cookson \& Eisenack, 1962) Stover \& Evitt, 1978 subsp. schiølerii subsp. nov.: 10, holotype, Turnhout -933 m, preparation 3, E.F. G37, high focus; 11,12, same specimen, sectional focus on processes and operculum; 13, same specimen, low focus. Scale bar $=30 \mu \mathrm{m}$. 
H. Slimani
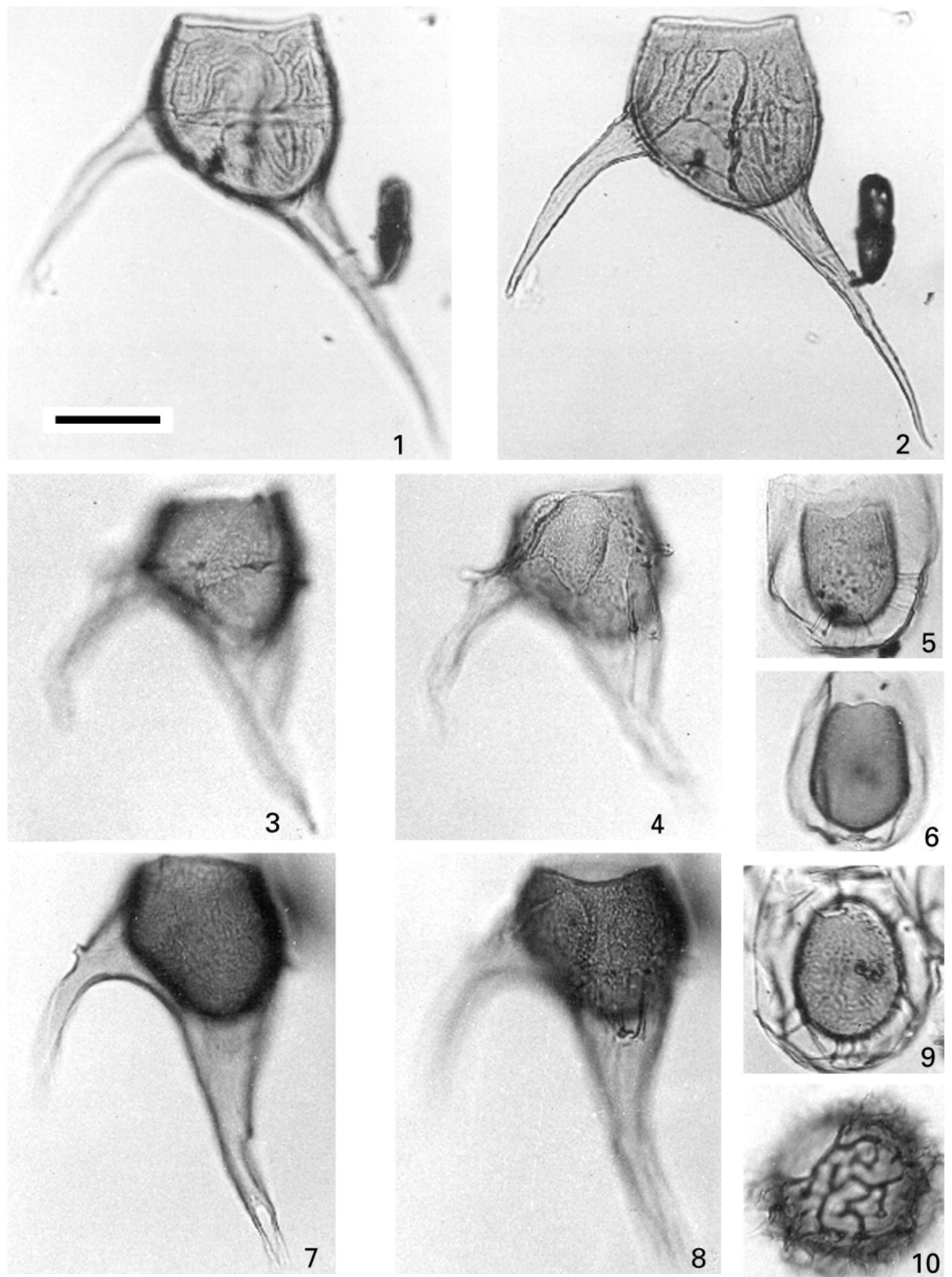
Campanian-Danian dinoflagellate cysts
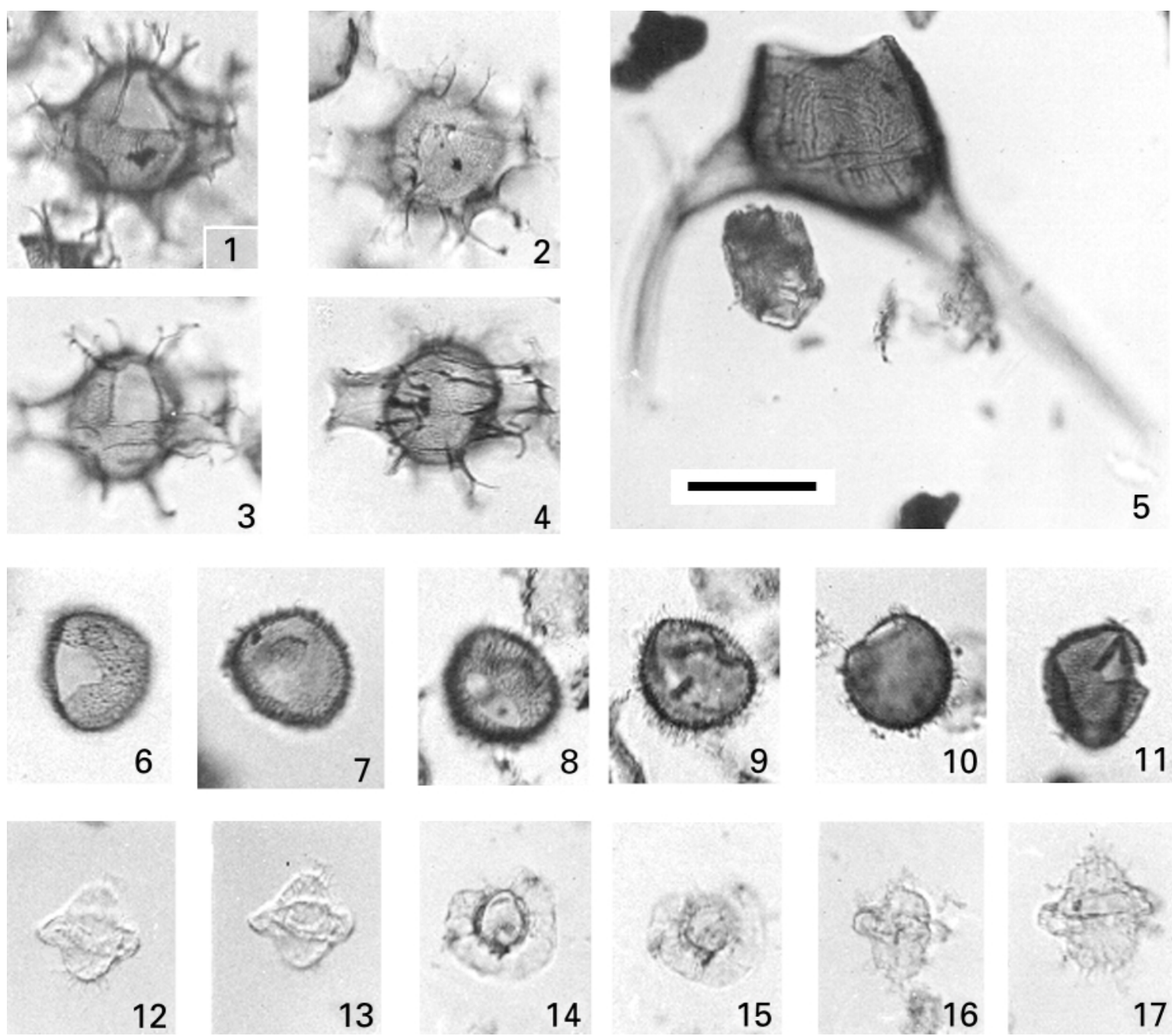

Explanation of Plate 3

Figs 1-4. Spiniferites ramosus (Ehrenberg, 1838) Loeblich Jr. \& Loeblich III, 1966 subsp. pterocoelus subsp. nov.: 1, holotype, Turnhout - $933 \mathrm{~m}$, preparation 5, E.F. R41/3, dorsal surface in low focus; 2, same specimen, ventral surface in high focus; 3, paratype, Turnhout - 933 m, preparation 5, E.F. Q29, dorsal surface in in low focus; 4, same specimen, ventral surface in high focus. Fig. 5. Odontochitina streelii sp. nov.: paratype, Beuteneken sample 20, preparation 2, E.F. F42/4, dorsal surface in low focus. Figs 6-11. Nexosispinum? complicatum sp. nov.: 6, Turnhout $-81589 \mathrm{~m}$, preparation 4, E.F. U48/4, dorsal surface in high focus; 7, same specimen, ventral surface in low focus; 8, Turnhout -775 $01 \mathrm{~m}$, preparation 1, E.F. F27/4, dorsal surface in low focus; 9, same specimen, ventral surface in high focus; 10, Turnhout - 739 $31 \mathrm{~m}$, preparation 1, E.F. X48, sectional focus on processes; 11, Turnhout -81589 m, preparation 1, E.F. Q54, dorsal surface with the two operculum pieces. Figs 12-17. Stephodinium? spinosum sp. nov.: 12, holotype, Turnhout $-940 \mathrm{~m}$, preparation 8, E.F. D53/2, ventral surface in low focus; 13, same specimen, dorsal surface in high focus; 14, Turnhout $-940 \mathrm{~m}$, preparation 6, E.F. T40, sectional focus on equatorial pericoel; 15, same specimen, polar surface in high focus; 16, Turnhout $-940 \mathrm{~m}$, preparation 8, E.F. F52/4-F53/3, right lateral view in low focus; 17, Turnhout $-940 \mathrm{~m}$, preparation 8, E.F. X45/4, dorsal surface in high focus. Scale bar $=30 \mu \mathrm{m}$.

\section{Explanation of Plate 2}

Figs 1,2. Odontochitina streelii sp. nov.: 1, holotype, Beutenaken, sample 20, preparation 1, E.F. X28/3, dorsal surface in low focus; 2, same specimen, ventral surface in high focus. Figs 3,4,7,8. Xenascus wetzelii sp. nov.: 3, holotype, Beutenaken, sample 2, preparation 1, E.F. E30/1, dorsal surface in low focus; 4, same specimen, ventral surface in high focus; 7, paratype, Hallembaye, sample 12, preparation 1, E.F. Q46/3, dorsal surface in low focus; 8, same specimen, ventral surface in high focus. Figs 5,6,9. Leberidocysta chlamydata (Cookson \& Eisenack, 1962) Stover \& Evitt, 1978 subsp. schiølerii subsp. nov.: 5, paratype. Turnhout $-933 \mathrm{~m}$, preparation 4, E.F. E43/1, ventral surface in high focus; 6, Turnhout $-933 \mathrm{~m}$, preparation 2, E.F. U37, sectional focus on processes; 9, Turnhout -933 m, preparation 4, E.F. E34/3, low focus. Fig. 10. Exochosphaeridium? masureae sp. nov.: paratype, Hallembaye, sample 18, preparation 3, E.F. F32/3, dorsal surface in high focus. Scale bar $=30 \mu \mathrm{m}$. 
Genus Pervosphaeridium Yun, 1981

Pervosphaeridium septatum sp. nov. (P1. 1, figs 3, 6-9)

1996 Pervosphaeridium septatum sp. nov. Slimani: 378-379, pl. 2, figs J-L, pl. 4, figs C, D.

1998 'Pervosphaeridium septatum' Slimani, 1996; Williams, Lentin \& Fensome: 476.

Type species. Pervosphaeridium pseudhystrichodinium (Deflandre, 1937) Yun, 1981.

Derivation of name. Septa connecting processes.

Diagnosis. Spherical to subspherical chorate cyst with fibroreticulate autophragm. Numerous solid, thin and distally bifurcate processes with truncate to slightly capitate distal end. Distinct apical process often present. High membranous septa better developed around processes and connecting them laterally. Paratabulation indicated only by precingular archaeopyle $2 \mathrm{P}\left(3^{\prime \prime}, 4^{\prime \prime}\right)$. Free operculum formed by loss of two paraplates.

Holotype. Turnhout -933 m, preparation 10, coord. E.F. U33 (Pl. 1, figs 7-9).

Type locality \& horizon. Turnhout $-933 \mathrm{~m}$. Campanian.

Dimensions. Holotype: maximal diameter of central body $60 \mu \mathrm{m}$, length of processes - 12-20 $\mu \mathrm{m}$, height of septa 8-18 $\mu \mathrm{m}$; other specimens: maximal diameter of central body $-54-64 \mu \mathrm{m}$, length of processes $-12-22 \mu \mathrm{m}$, height of septa $-6-20 \mu \mathrm{m}$. Specimens measured: 10.

Stratigraphical occurrence. Hallembaye: sample 1 (Lower Campanian); Turnhout: -987 up to $-933 \mathrm{~m}$ (Lower Campanian-Upper Campanian).

Remarks. Pervosphaeridium septatum sp. nov. differs from Pervosphaeridium monasteriense Yun (1981) by the high septa between the processes and by its more robust and bifurcate processes which are not as numerous as in $P$. monasteriense.

Genus Spiniferites Mantell, 1850; emend. Sarjeant, 1970

Spiniferites ramosus (Ehrenberg, 1838) Loeblich Jr. \& Loeblich III, 1966 subsp. pterocoelus subsp. nov.

(P1. 3, figs 1-4)

1996 Spiniferites ramosus (Ehrenberg, 1838) Loeblich Jr. \& Loeblich III, 1966 subsp. pterocoelus sp. nov. Slimani: 379, pl. 3, figs $\mathrm{H}-\mathrm{J}$, pl. 4, figs $\mathrm{E}-\mathrm{G}$.

1998 Spiniferites ramosus (Ehrenberg, 1838) Loeblich Jr. \& Loeblich III, 1966 subsp. 'pterocoelus' Slimani, 1996; Williams, Lentin \& Fensome: 579.

Type species. Spiniferites ramosus (Ehrenberg, 1838) Mantell, 1850.

Derivation of name. Lateral pericoels resembling two wings (wing=pteron).

Diagnosis. Chorate cyst with two subsquare lateral pericoels and subspherical endocyst. Densely granulate endophragm and smooth periphragm appressed between pericoels. Sexiform gonyaulacoid (S) paratabulation, indicated by parasutural septa and gonal and intergonal processes; 4 apicals (A,B,C and $1 \mathrm{u}$ ), 6 precingulars (2-1i), 6 cingulars (au-e), 6 poscingulars (Iu-VI), X sulcals, 1 antapical (Y) and 1 posterior intercalarie (X). Trifurcate gonal processes and bifurcate intergonal processes with bifid to bifurcate distal end. Parasutural septa better developed in areas where the endophragm and the periphragm are appressed. Strongly levorotatory paracingulum. Precingular archaeopyle $\mathrm{P}\left(3^{\prime \prime}\right)$. Free operculum formed by loss of one paraplate.

Holotype. Turnhout -933 m, preparation 5, coord. E.F. R41/3 (Pl. 3, figs 1, 2).

Paratype. Turnhout -933 m, preparation 5, coord. E.F. Q29 (Pl. 3, figs 3, 4).

Type locality \& horizon. Turnhout -933 m. Campanian.

Dimensions. Holotype: maximal diameter of endocyst $-34 \mu \mathrm{m}$, width of pericyst - $54 \mu \mathrm{m}$; paratype: maximal diameter of endocyst $-34 \mu \mathrm{m}$, width of pericyst $-60 \mu \mathrm{m}$; other specimens: maximal diameter of endocyst $-28-40 \mu \mathrm{m}$, width of pericyst 50-70 $\mu \mathrm{m}$. Specimens measured: 13 .

Stratigraphical occurrence. Beutenaken: sample 1,2 (Lower Campanian-Upper Campanian); Hallembaye: sample 1, 43 (Lower Campanian, Upper Maastrichtian); Turnhout: -987 up to $-73931 \mathrm{~m}$ (Lower Campanian-Danian).

Remarks. Spiniferites ramosus subsp. pterocoelus subsp. nov. differs from Spiniferites cruciformis Wall \& Dale in Wall et al. (1973) by its subspherical endocyst. The lateral pericoels mark the difference with Spiniferites ramosus subsp. granomembranaceus Davey \& Williams (1966a). In Rottnestia the pericoels are observed in antapical and ventroapical position.

Genus Stephodinium Deflandre, 1936; emend. Davey, 1970

Stephodinium? spinosum sp. nov.

(P1. 3, figs 12-17)

1996 Stephodinium? spinosum sp. nov. Slimani: 379-380, pl. 1, figs M-R.

1998 'Stephodinium? Spinosum' Slimani, 1996; Williams, Lentin \& Fensome: 584.

Type species. Stephodinium coronatum Deflandre, 1936.

Derivation of name. Processes on the central body.

Diagnosis. Small cavate cyst with ellipsoidal endocyst which is elongate in apical-antapical direction. Smooth to punctate periphragm and smooth endophragm appressed in apical and in antapical polar areas and in sulcal area. Equatorial pericoel interrupted ventrally. Cyst bearing thin, flexuous, solid or hollow and distally acuminate processes, except in the equatorial area where the endophragm and the periphragm are separed to form the pericoel. Paratabulation not indicated. Precingular archaeopyle $\mathrm{P}\left(3^{\prime \prime}\right)$ rarely perceptible with adnate operculum.

Holotype. Turnhout $-940 \mathrm{~m}$, preparation 8, coord. E.F. D53/2 (Pl. 3, figs 12, 13).

Type locality \& horizon. Turnhout $-940 \mathrm{~m}$. Campanian.

Dimensions. Holotype: length of central body $-24 \mu \mathrm{m}$, width of central body $-18 \mu \mathrm{m}$, height of equatorial pericoel $-8 \mu \mathrm{m}$, width of equatorial pericoel $-8 \mu \mathrm{m}$; other specimens: length of central body $-24-32 \mu \mathrm{m}$, width of central body $-15-20 \mu \mathrm{m}$, heigh of equatorial pericoel $-6-10 \mu \mathrm{m}$, width of equatorial pericoel 7-10 $\mu \mathrm{m}$; length of processes $-4-9 \mu \mathrm{m}$. Specimens measured: 15 . Stratigraphical occurrence. Turnhout: -987 up to $-933 \mathrm{~m}$ (Lower-Upper Campanian).

Remarks. The tabulation which characterizes Stephodinium is not observed in Stephodinium? spinosum sp. nov. The processes on the apical and antapical areas, and the ventral interruption of the equatorial pericoel, mark the differences with Stephodinium 


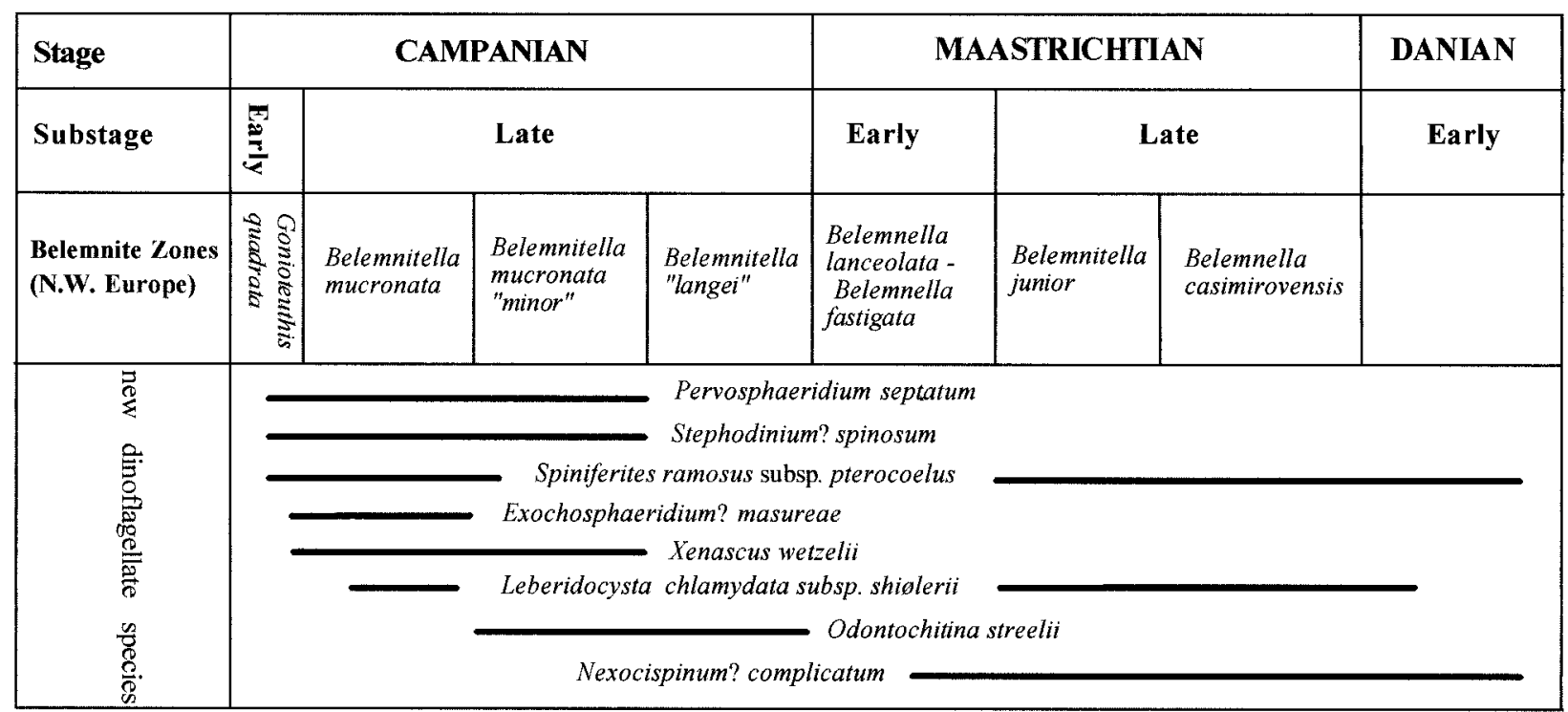

Fig. 5. Stratigraphic distribution of the new taxa.

pellucidum Deflandre (1943) and with Stephodinium? parvum De Coninck (1986).

Genus Xenascus Cookson \& Eisenack, 1969; emend. Yun, 1981; emend. Stover \& Helby, 1987

Xenascus wetzelii sp. nov.

(P1. 2, figs 3, 4, 7, 8)

1971 Odontochitina sp. Wilson: pl. 2, figs 1,2.

?1973 Odontochitina costata Alberti, 1961; Corradini: pl. 28, fig. 8 .

1977 'Odontochitina wetzelii' Wilson, 1974; Schumacker-Lambry in Streel et al.: pl. 3, fig. 8.

1985 'Odontochitina wetzelii' Wilson, 1974; Foucher in Robaszynski et al.: figs 21, 22, pl. 10, figs 9, 10, 11, 12.

?1991 Odontochitina sp. A Kirsch: 46, pl. 24, figs 7, 8,.

1996 Xenascus wetzelii sp. nov. Slimani: 380-381, fig. 7, pl. 3, figs F, G, Pl. 4, figs A, B.

1998 'Xenascus wetzelii' Slimani, 1996; Williams, Lentin \& Fensome: 644.

Type species. Xenascus australiensis Cookson \& Eisenack, 1969.

Derivation of name. In honour of Otto Wetzel who was one of the pioneers of Cretaceous dinocyst research in Germany.

Diagnosis. Cornucavate to circumcavate cyst with 1 apical, 1 antapical and 1 precingular horn. These are often bifurcate ditally. The thick and microreticulate endophragm and thin and smooth periphragm are appressed between the horns. Corniforme gonyaulacoide paratabulation indicated by low parasutural crests and short gonal, solid or hollow, distally acuminate or bifurcate to trifurcate processes; 4 apicals, 6 precingulars (2-1i), $\mathrm{X}$ cingulars, 5 postcingulars (II-VI), $\mathrm{X}$ sulcals, 1 antapical and 1 posterior intercalarie (X). Paracingulum and parasulcus not subdivided. Apical archaeopyle with free operculum.
Holotype. Beutenaken sample 2, preparation 1, coord. E.F. E30/1 (Pl. 2, figs 3, 4).

Paratype. Hallembaye sample 12, preparation 1, coord. E.F. Q46/3 (Pl. 2, figs 7, 8).

Type locality \& horizon. Beutenaken sample 2. Campanian. Dimensions. Holotype: length of central body (without operculum) $-50 \mu \mathrm{m}$, width of central body $-54 \mu \mathrm{m}$, length of lateral horn $-54 \mu \mathrm{m}$, length of antapical horn $-66 \mu \mathrm{m}$; paratype: length of central body (without operculum) $-56 \mu \mathrm{m}$, width of central body $-54 \mu \mathrm{m}$, length of lateral horn $-60 \mu \mathrm{m}$, length of antapical horn $-84 \mu \mathrm{m}$; other specimens: length of central body (without operculum) $-53-60 \mu \mathrm{m}$, width of central body $-60-90 \mu \mathrm{m}$, length of the two horns $-90 \mu \mathrm{m}$; length of processes $-4-16 \mu \mathrm{m}$. Specimens measured: 8 .

Stratigraphical occurrence. Beutenaken: sample 2-11 (Upper Campanian); Hallembaye: sample 1-33 (Lower-Upper Campanian); Turnhout: -96650 up to $-932 \mathrm{~m}$ (Upper Campanian.).

Stratigraphical and geographical distribution. Germany [Kirsch (1991): Early-Middle Campanian]; Belgium and the Netherlands [Wilson (1971, 1974): Late Campanian (B. mucronata Zone); Foucher in Robaszynski et al. (1985): Late Campanian (B. mucronata Zone)-Early Maastrichtian (B. lanceolata Zone)]; Belgium [Schumacker-Lambry in Streel et al. (1977) Late Campanian; in Louwye (1991): Campanian]; Italy [Corradini (1973): Senonian].

Remarks. Xenascus wetzelii subsp. nov. differs from Xenascus esbeckianus Yun (1981) by its reticulate (rather than granulate) endophragm, by its narrower and distally, often bifurcate, horns of which the postcingular and the antapical do not clearly communicate with each other.

\section{DINOFLAGELLATE STRATIGRAPHY}

The stratigraphical distribution of the new taxa is summarized in Fig. 5. The restricted stratigraphical occurrence of 
Pervosphaeridium septatum sp. nov. and Stephodinium? spinosum sp. nov. suggests that they are important stratigraphic species in the Campanian. The first and the last appearances of Exochosphaeridium? masureae sp. nov., Xenascus wetzelii sp. nov. and Odontochitina streelii sp. nov. and the first appearance of Leberidocysta chlamydata subsp. schilerii subsp. nov. are considered important stratigraphical markers for the Late Campanian. The first appearance of Nexocispinum? complicatum is within the Lower Maastrichtian.

\section{ACKNOWLEDGEMENTS}

Thanks are given to Dr J. De Coninck (Laboratory of Palaeontology, Institute of Geology, University of Gent, Belgium) for critical comments and constructive advice for the improvement of this manuscript and to R. Fensome (Geological Survey of Canada) who informed me that the new taxa described in my 1996 paper had to be validated.

\section{Manuscript received 26 February 1999 Manuscript accepted 10 January 2001}

\section{REFERENCES}

Alberti, G. 1961. Zur Kenntnis mesozoischer und alttertiärer Dinoflagellaten und Hystrichosphaerideen von Nord-und Mitteldeutschland sowie einigen anderen europäischen Gebieten. Palaeontographica, Abteilung A, 116: 1-58.

Bint, A. N. 1986. Fossil Ceratiaceae: A restudy and new taxa from the mid-Cretaceous of the Western Interior, U.S.A. Palynology, 10: $135-180$.

Clarke, R. F. A. \& Verdier, J.-P. 1967. An investigation of microplankton assemblages from the Chalk of the Isle of Wight, England. Verhandelingen der Koninklijke Neder-landsche Akademie van Wetenschappen, afdeling Natuur-kunde, Eerste Reeks, 24: 1-96.

Clarke, R. F. A., Davey, R. J., Sarjeant, W. A. S. \& Verdier, J.-P. 1968. A note on the nomenclature of some Upper Cretaceous and Eocene Dinoflagellate taxa. Taxon, 17: 181-183.

Cookson, I. C. \& Eisenack, A. 1962. Additional microplankton from Australian Cretaceous sediments. Micropaleontology, 8(4): 485-507.

Cookson, I. C. \& Eisenack, A. 1969. Somes microplankton from two bores at Balcatta, Western Australia. Journal of the Royal Society of Western Australia, 52: 3-8.

Corradini, D. 1973. Non-calcareous microplankton from the Upper Cretaceous of the Northern Apennines. Bollettino della Societa Paleontologica Italiana, 11: 119-197.

Davey, R. J. 1970. Non-calcareous microplankton from the Cenomanian of England, northern France and North America, Part II. Bulletin of the British Museum Natural History (Geology), 18(8): 333-397.

Davey, R. J. 1979. Marine Apto-Albian palynomorphs from Holes 400A and 402A, IPOD Leg 48, northern Bay of Biscay. In Montadert, L. \& Roberts, D. G. (eds) Initial Reports of the Deep Sea Drilling Project, Washington XLVIII, 546-577.

Davey, R. J. \& Williams, G. L. 1966a. The genera Hystrichosphaera and Achomosphaera. In Davey, R. J., Downie, C., Sarjeant, W. A. S. \& Williams, G. L. (Eds), Studies on Mesozoic and Cainozoic dinoflagellate cysts. Bulletin of the British Museum, Natural History (Geology), Supplement, 3, 28-52.

Davey, R. J., Downie, C., Sarjeant, W. A. S. \& Williams, G. L. 1966b. Studies on Mesozoic and Cainozoic dinoflagellate cysts. Bulletin of the British Museum, Natural History (Geology), Supplement, 3: 53-106.

De Coninck, J. 1986. Organic walled phytoplankton from the Bartonian and Eo-Oligocene transitional deposits of the Woensdrecht Borehole, Southern Netherlands. Mededelingen Rijks Geologische Dienst, nieuwe serie, 40(2): 1-49.

Deflandre, G. 1935. Considérations biologiques sur les microorganismes d'origine planctonique conservés dans les silex de la craie. Bulletin biologique de la France et de la Belgique, 69: 213-244.
Deflandre, G. 1936. Les flagellés fossiles. Aperçu biologique et paléontologique. Rôle Géologique. Actualités scientifiques et industrielles, 335: 1-97.

Deflandre, G. 1937. Microfossiles des silex crétacés. Deuxième partie. Flagellés incertae sedis Hystrichosphaeridés. Sarcodinés. Organismes divers. Annales de Paléontologie, 26: 51-103.

Deflandre, G. 1943. Sur quelques nouveaux dinoflagellés des silex crétacés. Bulletin de la Société Géologique de France, 13: 499-509.

Deflandre, G. \& Cookson, I. C. 1955. Fossil microplankton from Australian Late Mesozoic and Tertiary sediments. Australian Journal of Marine and Freshwater Research, 6: 242-313.

Ehrenberg, C. G. 1838. Über das Massenverhältniss der jetzt lebenden Kiesel-Infusorien und über ein neues Infusorien-Conglomerat als Polierschiefer von Jastraba in Ungarn. Königliche Akademie der Wissenschaften zu Berlin, Abhandlungen, 1836: 109-135.

Evitt, W. R. 1985. Sporopollen in dinoflagellate cysts. Their morphology and interpretation. American Association of Stratigraphic Palynologists Foundation, Dallas, 333pp.

Foucher, J. C. 1983. Les Dinokystes des Craies CampanoMaastrichtiennes d'Halembaye (Belgique) et de Beutenaken (PaysBas). Inventaire et répartition stratigraphique VIIIème Symposium de l'Association des Palynologues de Langue Française, Paris, 2pp.

Foucher, J. C. 1985. Dinoflagellates. In Robazynski, F., Bless, M. J. M., Felder, P. J., Foucher, J.-C., Legoux, O., Manivit, H., Meessen, J. P. M. h. \& Van der Tuuk, L. A. (Eds), The Campanian-Maastrichtian Boundary in the chalky facies close to the type-Maastrichtian area. Bulletin des Centres de Recherche Exploration-Production Elf-Aquitaine, 9 (1), 32-40.

Ioannides, N. S. 1986. Dinoflagellate cysts from Upper CretaceousLower Tertiary Sections, Bylot and Devon Islands, Arctic Archipelago. Bulletin of the Geological Survey of Canada, 371, 99pp.

Kirsch, K.-H. 1991. Dinoflagellaten-Zysten aus der Oberkreide des Helvetikums und Nordultrahelvetikums von Oberbayern. Münchner Geowissenschaftliche Abhandlungen, Geologie und Paläontologie, A22, 306pp.

Lentin, J. K. \& Williams, G. L. 1989. Fossil Dinoflagellates: index to genera and speciesAmerican Association of Stratigraphic Palynologists 20, 473pp.

Lentin, J. K. \& Williams, G. L. 1993. Fossil dinoflagellates: index to genera and species, 1993 edition. American Association of Stratigraphic Palynologists Foundation, 28, 856pp.

Loeblich, A. R. \& Loeblich, A. R. III. 1966. Index to the genera, subgenera, and sections of Pyrrophyta. Studies in Tropical Oceanography, Miami 3, 94pp.

Louwye, S. 1991. De dinophyceae uit het boven-krijt van west-Belgiè: systematiek, Biostratigrafie. $\mathrm{PhD}$ thesis. Faculteit Wetenschappen, Rijksuniversiteit Gent, Gent, Belgium, 289pp.

Mantell, G. A. 1850. A pictorial atlas of fossil remains, consisting of coloured illustrations selected from Parkinson's "Organic remains of a former world', and Artis's 'Antediluvian phytology', 208pp.

Marheinecke, U. 1986. Dinoflagellaten des Maastrichtium der Grube Hemmoor (Niedersachsen). Geologisches Jahrbuch, A93: 3-93.

Marheinecke, U. 1992. Monographie der Dinozysten, Acritarcha und Chlorophyta des Maastrichtium von Hemmoor (Niedersachsen). Palaeontographica, B227: 1-173.

Masure, E. 1985a. Les Kystes de Dinoflagellés de l'Autoroute A10. Cretaceous Research, 6: 199-206.

Masure, E. 1985b. Kystes de dinoflagellés. In Neumann, M., Platel, J. P. \& Andreief, P. (Eds), Le Campanien stratotypique: étude lithologique et micropaléontologique. Géologie Méditerranéenne, 10 (3-4), 41-57.

Sarjeant, W. A. S. 1970. The genus Spiniferites Mantell, 1850 (Dinophyceae). Grana, 10: 74-78.

Schioler, P. \& Wilson, G. J. 1993. Maastrichtien dinoflagellates Zonation in the Dan field, Danish North Sea. Review of Palaeobotny and Palynology, 78: 321-351.

Schioler, P., Brinkhuis, H., Roncaglia, L. \& Wilson, G. 1997. Dinoflagellate biostratigraphy and sequence stratigraphy of the Type Maastrichtian (Upper Cretaceous), ENCI Quarry, The Netherlands. Marine Micropaleontology, 31: 65-95.

Schumacker-Lambry, J. 1977. Microfossiles végétaux ?planctoniques. In Streel, M., Bick, H., Fairon-Demaret, M., Schumacker-Lambry, J. \& Vanguestaine, M. Macro- et microfossiles végétaux dans le contexte 
litho- et biostratigraphique du Sénonien-Paléocène de la rive gauche de la Meuse au Nord de Liège, BelgiqueLivret-guide de l'excursion du 22 septembre 1977 à l'occasion du symposium "Apport des techniques récentes en Palynologie', 87pp.

Slimani, H. 1994. Les Dinokystes des Craies du Campanien au Danien à Halembaye, Turnhout (Belgique) et à Beutenaken (Pays-Bas). Mémoires pour servir à l'Explication des Cartes Géologiques et Minières de la Belgique, 37, 173pp.

Slimani, H. 1995. Les dinokystes des craies du Campanien au Danien à Hallembaye et Turnhout (Belgique) et à Beutenaken (Pays-Bas): Biostratigraphie et systématique. PhD thesis. Laboratorium voor Paleontologie, Rijksuniversiteit Gent, Gent, Belgium, 540pp.

Slimani, H. 1996. Les dinokystes des craies du Campanien-Danien à Hallembaye et Trnhout (Belgique) et à Beutenaken (Pays-Bas). Supplément de systématique. Annales de la Société Géologique de Belgique, 117(2): 371-391.

Stover, L. E. \& Evitt, W. R. 1978. Analyses of pre-Pleistocene organicwalled dinoflagellates. Stanford University, Geological Sciences, 15: $1-300$.

Stover, L. E. \& Helby, R. 1987. In Jell, P. A. (Ed.), Studies in Australian Mesozoic palynology. Association of Australian Palynologists 4, 101295.

Stover, L. E. \& Williams, G. L. 1987. Analyses of Mesozoic and Cenozoic organic-walled dinoflagellates 1977-1985. American
Association of Stratigraphic Palynologists, Contribution Series, 18 : $1-243$.

Thomas, J. E. \& Cox, B. M. 1988. The Oxfordian-Kimmeridgian Stage boundary (Upper-Jurassic): Dinoflagellate cyst assemblages from the Harome Borehole, north Yorkshire, England. Review of Palaeobotany and Palynology, 56: 313-326.

Wall, D., Dale, B. \& Harada, K. 1973. Descriptions of new fossil dinoflagellates from the Late Quaternary of the Black Sea. Micropaleontology, 19: 18-31.

Wetzel, O. 1933. Die in organischer Substanz erhaltenen Mikrofossilien des baltischen Kreide-Feuersteins mit einem sedimentpetrographischen und stratigraphischen Anhang. Palaeontographica, Abteilung, A77: 141-188.

Williams, G. L., Lentin, J. K. \& Fensome, R. 1998. The Lentin and Williams index of fossil dinoflagellates. American Association of Stratigraphic Palynologists, 34, 418pp.

Wilson, G. J. 1971. Observations on European Late Cretaceous dinoflagellate cysts. Proceedings of the Second Planktonic Conference, Roma, 2: 1259-1275.

Wilson, G. J. 1974. Upper Campanian and Maastrichtian Dinoflagellate Cysts from the Maastricht Region and Denmark. PhD thesis. University of Nottingham, Nottingham, England, 601pp.

Yun, H.-S. 1981. Dinoflagellaten aus der Oberkreide (Santon) von Westfalen. Palaeontographica, B177: 1-89. 